\title{
Increased Ability to Face Disaster Threats for Children with Special Needs in Inclusion Elementary Schools at Yogyakarta City
}

\author{
Mahilda Dea Komalasari \\ Department of PGSD, FKIP, Universitas PGRI Yogyakarta \\ Jl. PGRI 1 Sonosewu No. 117, Sonosewu, Ngestiharjo, Kasihan, Bantul Regency, Special Region of Yogyakarta 55182, Indonesia \\ Tel. +62-274-376808, 418077, Fax. +62-274-376808 \\ Email: mahilda_dea@yahoo.com
}

\begin{abstract}
The potential for many disasters in the city of Yogyakarta needs to be addressed with a training to improve the ability to face disaster threats, especially for children with special needs. This training aims to increased ability to face disaster threats for children with special needs in inclusion elementary schools at Yogyakarta City. The capacity building training to face the threat of disaster was carried out by lecture, question and answer, and demonstration methods. This training took place at SDN Karanganyar and SDN Minggiran. Both of these elementary schools are inclusion in the city of Yogyakarta. Based on observations at SDN Karanganyar and SDN Minggiran, it is necessary to conduct training to improve the ability to face disaster threats to improve the ability to face disaster threats because there were students with special needs who did not understand how to protect and save themselves in the event of a disaster. Therefore, The goals of this community partnership program are teacher and students with special needs in SDN Karanganyar and SDN Minggiran, and implemented from February 2018 to October 2018. Through training to improve the ability to face disaster threats, it is expected to improve the ability of students with special needs in facing disaster threats.
\end{abstract}

Keywords: Children with special needs, Disaster, Inclusion, Training

\section{INTRODUCTION}

Training to improve the ability to deal with disaster threats for students with special needs in Karanganyar and Minggiran Elementary School needs to be implemented because of the low understanding of the ability to deal with disaster threats for residents of Karanganyar Elementary School and Minggiran Elementary School. In addition, the two schools are inclusive schools and there are students with special needs. Moreover, Karanganyar Elementary School and Minggiran Elementary School are in the city of Yogyakarta, which is a prone area for disasters, because Yogyakarta is flanked by two earthquakecausing points. This is in line with the statement of Tony Agus Wijaya (Head of the Yogyakarta Meteorology and Geophysics Agency (BMKG)), that there are two potential earthquake triggers in Yogyakarta. First, the source of the earthquake was centered in Potrobayan Hamlet, Srihardono, Pundong, Bantul. Secondly, the DIY region is a meeting between the Eurasian plate and Indo Australia. The subduction area is located 300 kilometers from the south coast. "If the area experiences movement, it will cause an earthquake (Markus Yuwono, 2016). In addition to DIY being near the confluence of two world plates, DIY is also on the path of an active volcano in the world. This position makes DIY vulnerable to natural tectonic earthquakes and volcanic earthquakes (Dwisiwi, 2012).

Seeing this condition is a consideration to find the right way to carry out mitigation efforts (prevention) so that it does not cause disaster for the local community, especially for students with special needs who school at Karanganyar Elementary School and Minggiran Yogyakarta Elementary School. In order to find alternative solutions to disaster problems appropriately, it is necessary to conduct training in capacity building to deal with disaster threats for students with special needs in Karanganyar Elementary School and Minggiran Elementary School to minimize the impact of disasters that can occur at any time.

Disaster mitigation training with a focus on improving the ability to face with disasters can be done in the early age so that children can find out how to save themselves when a disaster strikes. This training can be started from elementary school age because according to Piaget, this time is a concrete operational phase (Suhardjo, 2011; Harijanto, 2011).

In the implementation of this training, the training participants were given several disaster-related material, namely: (1) first day, teachers and students, especially students with special needs were provided with initial knowledge about the types of disasters, disaster management, Disaster Risk Reduction with the lecture method and disaster simulation; (2) second day, teachers are provided with knowledge of first aid material; (3) the third day, the teacher was given an understanding of the causes and control of fire, fire suppression, and the introduction of fire extinguishers using light fire extinguishers and traditional methods, and the practice of fire suppression using fire extinguishers and traditional methods of demonstration; (4) fourth day, the teacher is given an understanding of the history of the formation of the earth and the history of the occurrence of disasters; (5) 
fifth day, teachers are given an understanding of evacuation and spatial routes; and (6) sixth day, the teacher is given an understanding of the causes and consequences/impacts of the disaster.

Disaster mitigation simulations are carried out on students with special needs, which are introduced with the meeting point, safe places to take shelter from disasters, and ways to protect themselves from disasters (such as: protecting head while walking squat). Students with special needs are also given the introduction of evacuation routes to save themselves, including ways to temporarily mitigate disasters with the priority of handling students with special needs.

\section{MATERIALS AND METHODS}

\section{Study Area}

Training to improve the ability to face disaster threats for students with special needs in Karanganyar Elementary School and SDN Minggiran was conducted by lecture and demonstration methods.

\section{Procedures}

\section{Lecture}

The lecture method is used for socialization that aims to provide understanding to students with special needs about knowledge and attitudes facing earthquakes, floods and tornadoes, and socialization to explain the importance of environmental sustainability in order to prevent natural disasters, as well as socialization of geographic information related to potential disasters in The city of Yogyakarta. If the training participants are not clear about the material presented by the resource person, they can provide questions directly or do not have to wait for a question and answer session.

The use of the lecture method was combined by utilizing laptops and LCDs to display powerpoint material equipped with images, including video displays of earthquake disasters, floods and tornadoes in several regions and mitigation efforts. Laptops and LCDs are utilized considering the relatively large training material and limited training time. In addition, the use of laptops and LCDs to display several disaster events and also help training participants more easily understand the dangers of disasters that not only cause loss of property but can also cause casualties. The training participants after participating in this training activity are expected to increase their awareness to manage the surrounding environment well and at the same time participate in disaster mitigation efforts (Figure 1).

\section{Demonstration}

The demonstration method is used to carry out earthquake disaster mitigation, flood, and tornado simulations. The demonstration method is used to show the process of disaster and how to deal with disasters so that it can facilitate trainees in practicing how to deal with disasters (Figure $2 \& 3$ ).

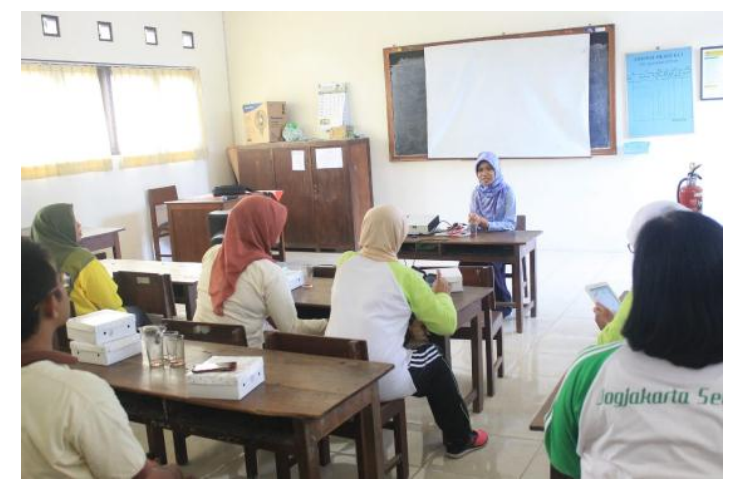

Figure 1. Delivering training materials through lecture.

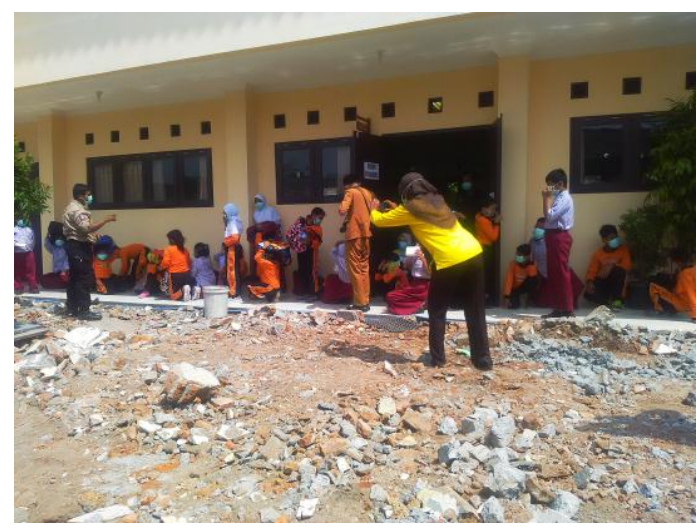

Figure 2. Earthquake disaster simulation.

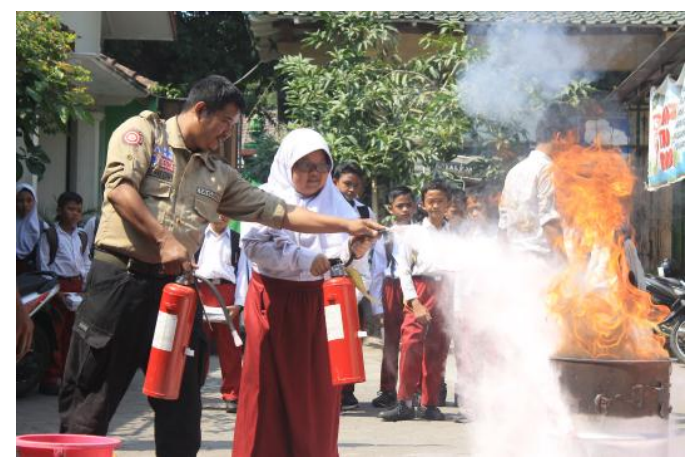

Figure 3. Simulation of using a fire extinguisher.

\section{RESULTS AND DISCUSSION}

The results of the implementation of training to increase the ability to deal with disaster threats for students with special needs in Karanganyar Elementary School and SDN Minggiran can be seen from an outline of the assessment of the following components, including: 


\section{Result-1 (The Success of the Target Number of Trainees)}

The target number of trainees is $90 \%$, while $93.75 \%$ of the training activities are present. The success of the target number of trainees is very good.

\section{Result-2 (Achievement of Training Objectives)}

The aim of the training was to equip training participants with knowledge about potential disasters in the Yogyakarta City area and provide alternative school-based disaster mitigation efforts in the form of capacity building training to face with disaster threats for students with special needs at Karanganyar Elementary School and Minggiran Elementary School. In the implementation of the training, some material was delivered briefly due to time constraints. The simulation was carried out after the material was delivered to improve the training participants' knowledge and skill. Achievement of training objectives is good.

\section{Result-3 (Achievement of Planned Material Targets)} The material that has been planned, among others: history of the formation of the earth and the history of the occurrence of disasters, evacuation and spatial pathways, causes and consequences / impacts of disasters, types of disasters, disaster management, Disaster Risk Reduction, disaster simulation, first aid, causes and control of fires, fire suppression, and introduction of fire extinguishers using the fire extinguishers and traditional fire extinguishers using the lecture method, as well as the practice of fire suppression using fire extinguishers and traditional. All training materials have been delivered to the training participants, but due to time constraints, not all materials are presented in detail, so that the achievement of the planned material targets is assessed as good.

\section{Result-4 (Ability of Training Participants in Mastering the Material) \\ Although the training time was relatively short, the ability of trainees in mastering the material was good.}

\section{Discussion}

The implementation of training to increase the ability to deal with disaster threats for students with special needs in Karanganyar Elementary School and SDN Minggiran was said to be successful and considered good. The success of the training activities to increase the ability to deal with disaster threats for students with special needs in Karanganyar Elementary School and SDN Minggiran can be seen from the satisfaction of the training participants after participating in the training activities. The training participants were very satisfied with the training activities to improve the ability to deal with disaster threats for students with special needs in Karanganyar Elementary School and Minggiran Elementary School because these activities could provide considerable benefits, including increasing training participants' knowledge about the potential for earthquake disasters, providing multisensory based disaster mitigation alternatives, and increase the awareness of trainees in supporting disaster mitigation efforts. With various benefits that can be obtained, it is expected that the training participants will always be vigilant and ready if at any time a disaster occurs in the school or in the area around his residence.

\section{CONCLUSIONS}

The implementation of training can be increase the ability to deal with disaster threats for students with special needs in Karanganyar Elementary School and SDN Minggiran. it can be seen from the satisfaction of the training participants after participating in the training activities.

\section{ACKNOWLEDGMENTS}

We thank KEMENRISTEKDIKTI for financial support through community partnership program grants.

\section{REFERENCES}

Dwisiwi, R.S., dkk. 2012. Pengembangan Teknik Mitigasi dan Manajemen Bencana Alam Gempa bumi bagi Komunitas SMP di Kabupaten Bantul Yogyakarta. Prosiding Seminar Nasional Penelitian. Halaman IPA-73-82.. Pendidikan dan Penerapan MIPA. Universitas Negeri Yogyakarta, June 2, 2012. [Indonesian]

Harijanto, S. (2011). The Insarannesian Goverment Policy on Special Education in Global Perspective pada International Seminar on Special Education, March 19, 2011. [Indonesian]

Markus Yuwono. 2016. Yogyakarta Diapit Dua Titik Penyebab Gempa. Okezone News. https://news.okezone.com/ diases pada tanggal July 9, 2018.

Suhardjo, D. 2011. Arti Penting Pendidikan Mitigasi Bencana dalam Mengurangi Resiko Bencana. Jurnal Cakrawala Pendidikan, Juni, Th. XXX, 2 
THIS PAGE INTENTIONALI Y LEIT BLANK 